\title{
RECENT CASES OF INTEREST TO OIL AND GAS LAWYERS
}

\author{
E. JOHN MOSS, Q.C.*
}

\begin{abstract}
Governmental involvement in the oil and gas industry is an area of increasing concern to the resource industry. The author reviews recent oil and gas decisions. Three major groups are examined; constitutional, caveats, and miscellaneous.
\end{abstract}

\section{INTRODUCTION}

Once again the past year has been one where the swift and ruthless impact of governmental decisions and statutory law have made the slight and slow-moving effect of judicial decisions almost an academic sideline of no practical relevance.

The constitutional lawsuits in Saskatchewan affecting various mineral resources labour on and since some attention was concentrated on the $C I G O L^{1}$ case last year, it has seemed appropriate to focus interest elsewhere in 1976 and the caveat cases have been selected for that purpose. In consequence, it has seemed a natural grouping of this paper to divide the cases into three, namely, miscellaneous cases, constitutional cases and the cases re caveats. This grouping has been followed in that order.

\section{MISCELLANEOUS CASES}

Lamb v. Canadian Reserve Oil and Gas Ltd.-[1976] 4 W.W.R. 79.

By this final judgment, the judgment of the Court of Appeal of Saskatchewan was set aside and the judgment of the District Court was restored, but varied so as to include compensation for loss of use of the land in the amount fixed by the Board of Arbitration. This complicated readjustment of the decisions of the various lower courts seems to have two significant results. The view of the Appellate Division of the Supreme Court of Alberta was followed as expressed in Caswell v. Alexandra Petroleums Ltd. ${ }^{2}$, namely that the presiding Judge ought not lightly to disturb the findings of the Arbitration Board and that it requires cogent evidence to establish where the Arbitration Board was wrong and why the award should be varied or revised upward or downward. The Supreme Court held that section 24(1)(a) of the Surface Rights Acquisition and Compensation Act $1968^{3}$ requires consideration to be given both for the value of the land and the loss of use of the land. It also appears that the Supreme Court approves the proposition that while the Blackstock formula for computation of the value of expropriated land should not be resorted to where there is evidence of other recent sales of comparable land in the district, it is appropriate where there are no comparable sales and where a small area is taken out of a large unit.

\footnotetext{
- Barrister and Solicitor, Balfour, Moss, Milliken, Laschuk, Kyle. Vancise and Cameron, Regina. Saskatchewan.

1. [1976] 2 W.W.R. 356 (Sask. C.A.).

2. (1972) 3 W.W.R. 706.

3. S.S. 1968 c. 73.
} 
Montreal Trust Company v. Gulf Securities Corporation et al.-(1975) 1 W.W.R. 689.

At last year's seminar the judgment of the Court of Appeal for Saskatchewan in this case was stated to be under appeal to the Supreme Court of Canada. ${ }^{4}$

Act Oils Limited v. Pacific Petroleums Ltd.-(1976) 60 D.L.R. (3d) 658 and (1976) 1 W.W.R. 369.

At last year's seminar it was mentioned that this case had been argued before the Appellate Division of the Alberta Supreme Court. The judgment dismissing the appeal was delivered in 22nd July, 1975 and is reported under the above-mentioned citation. Subsequently, application was made to the Appellate Division for leave to appeal to the Supreme Court of Canada. This leave was denied in the judgment reported under the above-mentioned citation. The matter was further pursued by an application to the Supreme Court of Canada for leave to appeal, which was denied.

The judgment last mentioned deals with the general principles upon which a provincial Court of Appeal shoud grant or deny leave to appeal to the Supreme Court of Canada. This is a discretionary matter which is quite unfettered and unchannelled although it should be exercised judicially and not merely out of caprice.

In the present case the court was of the view that all the issues involved could be properly dealt with by an interpretation of the particular terms of the agreement and concluded that there was neither a matter of public interest nor any important question involved; nor indeed, any other feature that in the court's opinion ought to be submitted to the Supreme Court of Canada for decision.

Regina v. The Steam Tanker "Evgenia Chandris"-(1976) 12 N.B.R. (2d) 652, reversing (1975) 8 N.B.R. (2d) 297.

At last year's seminar the decision of the Appeal Division of the New Brunswick Supreme Court in this case was mentioned which had created some difficulty inasmuch as it held that judicial notice could not be taken of statutory instruments within the scope of section 23 of the Statutory Instruments Act by reason of the fact that the actual publication was not produced in court. The Supreme Court of Canada has now decided that the fact of this publication needs no proof, but as a matter of courtesy to the court, Crown counsel at trial should have offered a copy of the regulations to the judge and to the defence. Failing this, the trial judge ought to have used his authority to tell the Crown to prove the regulations.

Anadarko Petroleum of Canada Ltd. v. Syd Johns Farms Ltd.-(1975) 6 W.W.R. 350 .

In this judgment the British Columbia Supreme Court considered an application on appeal by way of a stated case of the Mediation Arbitration Board established under the Petroleum and Natural Gas Act, 1965 (B.C.). Under the case stated the question arose whether the Board erred in considering the "Land Administration Division Report" setting out the policy of the British Columbia Government Lands Department regarding compensation to be paid, which report

4. Now reported in [1977] 2 W.W.R. 48. 
was considered after the hearing, without any opportunity for the appellant to make any submissions in respect of the matters raised by the report. The court held that the Board was engaged on a quasijudicial function and therefore should follow the principles of natural justice and failed so to do in considering evidence without giving the appellant an opportunity to reply thereto. The second question that arose was whether the Board was authorized to order that an annual rent be paid by the appellant pipeline company. The court held that the Board had no power to create an agreement between the parties and only the power to award compansation for the damage occasioned. Accordingly, it could not award a rental which inferred the creation of a lease or licence.

Home Oil Company Limited v. Page Petroleum Ltd.-[1976] 4 W.W.R. 598.

This judgment reaches the same result as the decision in Berkley v. Alminex, [1974] 1 W.W.R. 288, even though the wording of the formal agreement was different from that in the letter agreement.

Committee for Justice \& Liberty et al. v. National Energy Board-(1976) 68 D.L.R. (3d) 716.

On appeal from the federal Court of Appeal the Supreme Court of Canada held that a member of the National Energy Board was disqualified from sitting on hearings regarding applications for certificates of public convenience and construction relating to construction of an Arctic gas pipeline on the ground of the reasonable apprehension of bias by reason of the fact that such member had been an executive with the Canada Development Corporation, a Crown corporation which had, as a member of a consortium of companies, dealt with the implementation of the proposed pipeline scheme.

Re Alberta \& Southern Gas Co. Ltd. v. Cheuron Ltd. et al.-(1975) 59 D.L.R. (3d) 140.

The Trial Division of the Alberta Supreme Court dealt with an application to direct that a question of law, arising in the course of an arbitration to redetermine the price of gas under a contract of purchase and sale, should be submitted in the form of a stated case for determination by the coirut. It was held that a party for submission is not, as a matter of right entitled to an order for a stated case whenever a question of law arises in the course of an arbitration and it is a matter of discretion whether the order will go or not. In the case at bar the question requested to be submitted did not put an end to the arbitration as a whole and, since it was an important question on which a final determination was desirable, the court directed the issue of a stated case for determination of the point of law by the court.

Minister of National Revenue v. M. P. Drilling Ltd. -76 D.T.C. 6028 dismissing appeal from 74 D.T.C. 6343.

A decision of the Federal Appeal Court where the respondent taxpayer company incorporated in 1963 for the purpose of marketing liquified petroleum gases to the Far East, suffered substantial losses in 1964, 1965 and 1966. In 1966 the company abandoned its venture and commenced contract drilling and thereafter claimed the said 
losses as deductions in the 1967 and 1968 taxation years. The Minister disallowed the losses contending that they were not expenses incurred for the purpose of earning income and alternatively there was no income to which they might be attributed. The appeal to the Federal Court Trial Division was allowed and on further appeal to the Appeal Court such appeal was dismissed. The expenditures being made for the purpose of earning income were not of a capital nature and were therefore deductible by virtue of paragraph 12(1)(a) of the former Income Tax Act. The expenses were deductible even though they did not produce any income.

Lemesurier v. The Union Gas Co. of Canada Ltd.-(1976) 8 O.R. (2d) 152.

The defendant company was held liable in negligence for damages resulting from the explosion of gas from a range which had been installed by the defendant company in the plaintiff's home. The explosion which caused the damage was caused by a gas leak that took place because of a failure in the flexible metal connector fitted by the defendant company as part of the installation. It was held that the flexible metal connector had a deficient design of which the defendant should have been aware and the failure to recognize that deficiency constituted negligence in the installation of the cooking range.

The Interprovincial Pipeline Co. v. Seller's Oil Field Service Ltd.; Lloyd's of London et al., third party-(1976) 58 D.L.R. (3d) 719.

In this decision of the King's Bench in Manitoba questions arose as to the liability of insurers to indemnify the insured against a claim for damages caused by the insured in negligently cleaning some oil storage tanks. The case may therefore be said to have some connection with the oil and gas industry, but, in law, it is really an insurance case. The decision turns upon the particular definition of the wording of the insurance policy and lays down no fresh principle of law.

Wall et al. v. Interprovincial Pipeline Ltd.-(1976) 9 L.C.R. 97.

In this judgment, the Ontario Court of Appeal quashed appeals from some thirteen orders made by a County Court judge under the

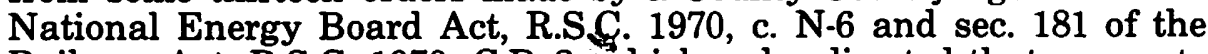
Railway Act, R.S.C. 1970, C.R.-2, which order directed that warrants for possession of thirteen tracts of land should issue upon payment into court of compensation for sub-surface easements and rights-ofway expropriated by the defendant company. The court followed a decision of the Supreme Court of Canada in Canadian Northern Ontario Railway Company v. Smith, ${ }^{5}$ in which it was decided that a judge under the predecessor section of the Railway Act was persona designata from whose order no appeal lay.

Golden Eagle Oil and Gas Ltd. v. Richardson Farms Ltd.-(1976) 9 L.C.R. 98.

In this judgment, the Saskatchewan Court of Appeal dealt with an application for leave to appeal to the court pursuant to $\mathrm{s}$. 52 of the Surface Rights Acquisition and Compensation Act ${ }^{6}$ from an award made by the Board of Arbitration constituted under the Act. The

5. (1914) 22 D.L.R. 265,50 S.C.R. 476

6. Supra, n. 3 as amended by s. 2 of S.S. 1974-75, c. 52 . 
statutory right of appeal now being limited to an appeal on a question of law or a question concerning the jurisdiction of the Board and then only with leave, the right is obviously very limited and the judgment of the court confirmed this fact. Leave was sought in respect of several grounds of appeal and all were denied save one. The court in general found that the grounds related to alleged errors of fact on which, even if the Arbitration Board had been wrong, no right of review arose. The court held that if the grounds of appeal involved a question of fact or a question of mixed fact and law, no right of appeal exists under the statute. Leave for appeal was given on one ground only, namely whether the Board had failed to consider the evidence before it concerning the owner's cost of operations in making its award of compensation and thereby proceeded on a wrong principle of law. One fact is now very clear, namely, that there is little scope for appeal from such arbitrations in Saskatchewan. ${ }^{\mathbf{a}^{\mathrm{a}}}$

Ozipko v. Northwestern Utilities Limited-not reported, Decision No. 76 4E.

This is the first decision under the new Alberta Expropriation Act? and was handed down by the Surface Rights Board on May 20, 1976. The decision determined the compensation payable in respect of an expropriation of a right of way for a pipeline for the transmission of natural gas and other hydrocarbon products.

The Surface Rights Board held that the date of registration of the Certificate of Approval at the Land Titles office is the date of taking for the purposes of determining compensation. In the expropriation of a right of way under section 55, the Surface Rights Board stated that there "is no sale of the land involved herein; title to the land does not transfer, only a certain portion of the bundle of rights inherent in fee simple ownership has been transferred to the Expropriating Authority". The Board awarded interest at $18 \%$ per annum.

\section{CONSTITUTIONAL CASES}

Canadian Industrial Gas \& Oil Ltd. v. Government of Saskatchewan and A-G Sask.-(1976) 2 W.W.R. 356.

The Saskatchewan Court of Appeal has affirmed the trial judgment in this case and, therefore, upheld the validity of the Oil and Gas Conservation, Stabilization and Development Act. ${ }^{8}$ Leave to appeal to the Supreme Court of Canada has been granted, but the appeal has not yet been argued.

In an earlier interlocutory judgment in the same case, ${ }^{9}$ the Court of Queen's Bench held that it was not possible to obtain a declatory judgment on an interlocutory application.

\section{POTASH CONSTITUTIONAL CASES}

Although not concerned with oil and gas, one cannot overlook the similar constitutional issues that have recently arisen within

6a.The case of Lamb v. Canadian Reserve Oil \& Gas Ltd. (previously mentioned in this paper), was, of course, dealt with under the procedure arising under the Surface Rights Acquisition and Compensation Act, 1968, prior to the amendment of 1974-75.

7. S.A. 1974 , c. 27

8. 1973-74, (Sask.)

9. [1974] 4 W.W.R. 557. 
Saskatchewan in the potash industry, resulting in a proliferation of litigation. The cases are indicated hereunder.

Central Canada Potash Co. Limited and A-G Canada v. A-G Sask., Minister of Mineral Resources for Saskatchewan and Government of Saskatchewan-(1975) 5 W.W.R. 193.

The Queen's Bench in Saskatchewan has declared invalid on constitutional grounds the Potash Conservation Regulations, 1969, the prorationing scheme and the directives and licenses implementing the scheme. The court admitted extrinsic evidence to decide what was the true intent and purpose of the legislation, including the circumstances leading to the passage of the legislation as well as evidence of its effect, oral and written statements of Ministers of the Crown as to the object or effect of the legislation, publications by the Queen's Printer and certain departmental publications, ministerial licences, directives, orders and rules. The court held that the real purpose of the regulations was to restrict and limit the export of potash to the United States as well as to control and impede the flow of trade between Saskatchewan and other Canadian provinces, unless the Minister's conditions were complied with. This constituted interference with trade and commerce, a matter which was beyond the competence of the provincial legislature. In consequence, the Orders-in-Council enacting the Potash Conservation Regulations went beyond the enabling powers in the Mineral Resources Act and were ultra vires. The court awarded damages against the Government of Saskatchewan in the sum of $\$ 1,500,000.00$.

The judgment has been appealed to and argued before the Saskatchewan Court of Appeal, but no judgment has yet been rendered.10 It must be noted that s. 6 and s. 7 of Bill 62 of 1976 has now been passed by the Legislative Assembly of Saskatchewan purporting to ratify and confirm the Potash Conservation Regulations with retroactive effect and it will be interesting to see whether this will be effective to reverse the trial judgment.

Because of the above cited judgment at trial, it would appear that (apart from the effect of the said Bill 62) the potash prorationing fees are irrecoverable not only because of their wording the person liable is one who "is licensed to produce and dispose of potash under the Potash Conservation Regulations, 1969", but also perhaps because Mr. Justice Disbery in the above-mentioned judgment has indicated that the whole potash prorationing scheme is invalid. At any rate, an action has been commenced to declare the potash proration fee regulations, 1972, invalid, being Cominco Ltd. et al. v. Government of Saskatchewan. This action is far from trial as yet, but the government applied to the Queen's Bench for a stay of the action in view of the pending appeal in Central Canada Potash Co. Limited v. Covernment of Saskatchewan. The Queen's Bench dismissed the application, but on appeal to the Court of Appeal, by judgment filed April 6, 1976, the Court of Appeal directed that the action dealing with the prorationing fees should not be set down for trial until the time for appeal to the Supreme Court of Canada from the judgment of the Court of Appeal, when rendered, in Central Canada Potash Co. Limited v. Government of Saskatchewan has expired. If within such

10. Now reported in [1977] 1 W.W.R. 487. 
time, leave to appeal is granted by the Supreme Court of Canada, then the action of the plaintiff in the prorationing fees case will not be entered for trial until the Supreme Court appeal has been heard and judgment rendered.

Meanwhile, further taxation has been imposed in the potash industry by virtue of the Potash Reserve Tax Regulations, 1974, and further action has been commenced to declare those regulations ultra vires, the action being Amax Potash Limited et al. v. Government of Saskatchewan. The taxation of the potash companies under these regulations are in such substantial amounts as to be estimated at present rates to be about $\$ 120,000,000.00$ per year. The plaintiffs are fearful under 8. 5(7) of the Proceedings Against the Crown Act, that if the regulations are ultimately found to be ultra vires, the amount paid will be irrecoverable. The plaintiffs, therefore, sought by application to the Queen's Bench in this action to obtain a court order under which the taxes might be paid and not to pay the taxes pursuant to the legislation. The court by order of September 18, 1975, refused the application feeling that it had no power to authorize a non-compliance with the clear provisions of the statute and the regulations. On appeal to the Court of Appeal, this decision was upheld ${ }^{11}$ and the Court of Appeal stated that the relief sought was specifically denied by s. 5(7) of the Proceedings Against the Crown Act. Leave has been granted by the Supreme Court of Canada ${ }^{12}$ to argue the constitutional point under 8. 5(7) and it is understood that the argument will take place in June, 1976. It appears to the writer inconceivable that taxes collected under an invalid taxing statute should be irrecoverable by the taxpayer and it is to be hoped that the Supreme Court will either find the proper interpretation of s. 5(7) does not bear such a meaning or that, if so, it is in itself an unconstitutional subsection.

Since the passage of the said Bill 62 (being an amendment to the Mineral Resources Act) it is understood that a further action has been commenced by the majority of the potash producers alleging breach of royalty contracts entered into between the companies and the Government of Saskatchewan.

Canex Placer Limited et al. v. A-G B.C. et al.-(1976) 1 W.W.R. 24.

In this case, the plaintiffs sought declarations that the Mineral Royalty Act, ${ }^{13}$ the Mineral Land Tax Act, ${ }^{14}$ and s. 15(2) of the Mineral Act ${ }^{15}$ were ultra vires and asked for injunctive relief. The question arose whether, in the light of the provisions of the Crown Proceedings Act (B.C.) and specifically, s. 11 thereof (which forbade an injunction against the Crown), appellants had a cause of action. The defendants, without filing a statement of defence, launched a motion to have the action struck out and this was successful at first instance. On appeal to the British Columbia Court of Appeal, it was held that the appellants had a cause of action and their action had been brought in proper form. The procedure under the Crown 
Proceedings Act was held to refer to actions against the Crown which formerly had been appropriate to be brought by way of petition of right and it was held that this did not abolish the old form of declaratory action which had always been available and still so remained.

\section{CASES RE CAVEATS}

In re Paulette and In re a Caveat with the Registrar of Titles of the Land Titles Office, Northwest Territories.

On November 12, 1975, the Court of Appeal of the Northwest Territories in the majority judgment reversed the decision of Mr. Justice Morrow reported in Paulette's Application to file a Caveat. ${ }^{16}$ The four judgments that constituted the majority in the Court of Appeal ${ }^{17}$ all held that s. 134(2) of the Land Titles Act ${ }^{18}$ did not justify the filing of a caveat in respect of unpatented lands save in a case where the grant of land had issued from the Crown but such grant had not been registered under the Land Titles Act. Mr. Justice Moir in the sole dissenting judgment held to the contrary contending that the plain meaning of the subsection was to permit the filing of a caveat before registration of title whether the lands were patented or not and he contended that this was in fact the practice of the registrars. This appears to be a crucial point of law since the writer would presume that there are many caveats already filed in reliance upon the position that $\mathbf{s}$. 134(2) permits a caveat to be filed against unpatented land.

There is some suggestion in the majority judgments that other reasons can justify the majority decision. For example, perhaps it can be defended on the basis that no claim can be filed that challenges the title of the Crown on which all grants of letters patent and their ultimate registration must depend. This is suggested by Mr. Justice McDermid and Mr. Justice Clement. Mr. Justice Clement also appears to find the claim asserted by the caveat to be of a nature that cannot be protected by a caveat because s. 132 of the Land Titles Act requires some measure of documentation which is not found in a claim to aboriginal rights.

It appears likely that the further appeal which may presumably be expected in this matter to the Supreme Court of Canada ${ }^{19}$ will settle the interpretation of s. 134(2). If the present judgment is confirmed, it may well have a marked effect upon the practice of oil and gas lawyers in relation to caveats and, if a caveat be ineffective in the case of unpatented lands, further consideration will need to be given as to what appropriate protection should be afforded a client in oil and gas transactions in respect of unpatented land. This may perhaps commend itself as the topic of some discussion at the seminar.

It is understood that a caveat, known as the Whitehead Caveat, has been submitted to the registrar of land titles in Alberta claiming "an interest of aboriginal rights on behalf of ourselves and as representatives of all the Indian people in the province of Alberta, similarly

16. (1973) 6 W.W.R. 97.

17. [1976] 2 W.W.R. 193.

18. R.S.C. 1970 , c. L-4.

19. Now reported in [1977] 1 W.W.R. 321. 
entitled by virtue of unextinguished aboriginal rights, to and in all that tract of land, etc. ..." The land in question comprises a substantial area of northern Alberta, bordering on Fort McMurray in the east, extending to the Peace River Country in the west and no doubt includes part of the Athabasca tar sands. The registrar referred the matter to a judge of the Supreme Court for a determination as to whether or not the caveat should be accepted for registration.

It may be noted that the Paulette decision is not likely to affect Saskatchewan practice, since s. 155(2) of the Land Titles Act clearly permits a practice that would be consistent with the minority judgment in the Paulette case. It is worded as follows:

155(2) A caveat may be filed against land for which no transfer or grant from the Crown has issued, and in such case the registrar shall, on receipt of the caveat, enter the same in the instrument register, and endorse upon the certificate of title, when one is granted, a memorandum of the caveat. 